\title{
Grade Ten Teachers' Understanding of Multiple Intelligences in Teaching Physical Science in the Rural Context
}

\author{
N. Pearl Blose \\ ORCID iD: https://orcid.org/0000-0003-0843-7277 \\ Blanche N. Hadebe-Ndlovu \\ ORCID iD: https://orcid.org/0000-0002-3506-7382
}

\begin{abstract}
Understanding multiple intelligences in teaching is very important in order to achieve effective teaching. The most important motivation for this research is to show some of the observable structures of a holistic and constructively enriched curriculum for physical science that shapes the strengths of learners within the classroom. Human intelligence varies so much that each learner has a unique combination of intelligences resulting in a unique personal profile for each learner. As a result, each learner learns in a unique way. The purpose of this study was to explore physical science teachers' understanding of multiple intelligences in teaching. It is then very important for teachers to understand multiple intelligences teaching, so that they may reach every learner when teaching. The traditional ways of teaching catered for only mathematical and linguistic intelligences, leaving learners with other intelligences behind. When traditional ways of teaching are used, physical science is viewed as a difficult subject, because most learners fail the subject. This article presents an interpretive case study of four research participants who are grade ten, physical science teachers in a rural school in Durban, KwaZulu Natal. For data generation, narratives, one on one semi-structured interviews and classroom observations were used. The study concluded that even though physical science teachers are showing the visibility of understanding multiple intelligences, they cannot articulate what multiple intelligences are. Yet, in their
\end{abstract}


teaching there was visibility of the understanding of multiple intelligences, as they use multiple intelligences strategies unknowingly especially when they use visual aids.

Keywords: learning, multi-intelligence, physical science teaching, understanding, subject

\section{Introduction}

For effective teaching and learning of Physical Science, a school should have the following resources; teachers, learners, a laboratory, textbooks, science apparatuses and chemicals. Yet, in rural schools 'Everything connected with education, apart from learners has been in short supply, schools, classrooms, teachers, teaching materials indeed everything needed for proper education of youth is in short supply' (Ukeje as cited in Akinmade 1999). When the resources are a problem, teaching and learning is affected negatively, also impacting pass rates. Over the past years, the pass rate of Physical Science has been very low (DoE 2001). Some schools have laboratories but lack apparatuses and chemicals, because Physical Science is a practical, experimental subject. It then becomes difficult to teach it effectively. Although the DoE supplies some books, there is a great challenge in distribution. Some of these resources may be improvised to some degree. Yet, teachers cannot be improvised. They are in short supply as well.

In addition, rural communities are challenged because most of the parents are not working, and they cannot afford to support their children financially, in cases where there are school requirements to be bought. In the rural areas in South Africa, there are some schools that do remarkably well at producing good matric results in Physical Science and Mathematics. These schools achieve their success in spite of the poverty around them and lack of facilities and resources (Burney \& Beilke 2008). The Department of Education (2001) suggests that the improvement of learner achievement in Physical Sciences and Mathematics depends on competent teaching. In this study it is assumed that, competent teaching can be realised if teachers would understand and employ multi intelligences teaching in Physical Science, which will cater for all learners with their different intellectual abilities. 


\section{Research Objectives}

- To explore teachers' understanding of multiple intelligences, in teaching physical science.

- To explore why teachers understand multiple intelligences in physical science in particular ways.

\section{Research Questions}

- What are Grade ten teachers' understandings of multiple intelligences teaching in Physical Science?

- How do Grade ten teachers indeed understand multiple intelligences, and teaching in Physical Science in particular ways?

\section{Research Design and Methodology}

This is an interpretive qualitative case study of eight grade ten physical science teachers, in a secondary school in Durban in a rural context. The exploratory case study was suitable because this study was aimed at exploring Grade ten teachers' understanding of multiple intelligences teaching in Physical science.

\section{Sampling}

Purposive sampling was used in selecting all four participants. To recruit the participants, the principal of this rural secondary school was asked to identify the grade 10 physical science teachers, and then they were asked in writing to participate in the study. As Behi and Nolan (1995) maintains that every human being has a right to privacy, therefore each research participant was required to give written consent of participation. Research participants were guaranteed their anonymity and confidentiality at all times.

\section{Literature}

It is assumed that there is a correlation between the uses of multiple intelligences strategies and academic achievement. Therefore, it is hypothesised that learners who are taught using multiple intelligences strategies will have higher academic achievements than those learners who are taught in traditional ways. 
Most learners find themselves in a classroom that places too much emphasis on linguistic, word-smart intelligence or mathematical, number-smart intelligence. Campbell, Campbell and Dickinson (1996) maintain that sometimes teachers unconsciously use MI theories in their teaching, like when they use visual aid or playing a song. If they fully understand MI theories and its benefits; it could be more beneficial to them in their teaching.

\section{The Concepts of Understanding and Multiple Intelligences}

Understanding is a psychological process related to a matter such as a person, situation, or message. Understanding is a relation between a person and an object of understanding. Understanding implies abilities and dispositions with respect to an object of knowledge that are sufficient to support intelligent behaviour. Understanding is related to learning concepts, and theories associated with those concepts. Thus, understanding is correlated with the ability to make inferences (Wikipedia). If you have an understanding of something, you know how it works or know what it means (Collins 2004). According to Gardner (1999) intelligence is the ability to solve problems and to create issues in the cultural medium in order to progress. Individual learners possess intellectual abilities which enable them to solve problems, create products or provide services that are valued in the larger society (Howard 1983). MI is concerned about, in what ways are learners smart, rather than, asking are they smart. MI theories brought new insights into education, helping students to identify and develop their strengths and discovering more effective teaching methods. Gardner (1983) states that all the eight intelligences are equally important and essential to an individual's development. Therefore, development in one area often increases the chances of development of another. Gardner asserts that when it comes to being smart, differences count. The theory takes individual differences seriously, appreciating the giftedness of each individual. It is highly important for teachers to understand MI theories and how to apply it to their teaching.

\section{The Importance and Benefits of Understanding and Using Multiple Intelligences in Teaching Physical Science}

Multiple Intelligences theory in the classroom has many benefits: the teacher and learners using it realise that there are many ways to be 'smart'. All forms 
of intelligence are equally important. It is important for teachers to understand multiple intelligences. A sense of increased self-worth may be seen as learners develop their strengths and work towards being experts in certain areas. Learners may develop strong problem solving skills that they can use those skills in real life situations (Giles, Pitre \& Womack 2003). Stanford (2003) explains that multiple intelligences teaching provides a way of being competent as a teacher. Multiple intelligence teaching provides many different ways for learners to learn and to show evidence of their learning. According to Kagan (2000), teachers should understand and use multiple intelligences in the classroom, because it will prepare learners for future's complex life challenges. Multiple Intelligence teaching makes the curriculum accessible to all learners. It also keeps the subject content exciting to all learners. Learners should be taught based on their capabilities of learning. Benefits of using multiple intelligences teaching includes reduced discipline and classroom management problems, it also increases learners engagement and enthusiasm for learning (Christensen, Johnson \& Horn 2010). Teaching that includes non-academic intelligences is also beneficial, for learners from non-English-speaking backgrounds, who were not linguistically strong in English. Learners who had a low academic self-confidence demonstrated more confidence and competence when they were able to present what they had learned in their area of strength (Noble 2004). Benefits of using multiple intelligences teaching includes reduced discipline and classroom management problems, it also increases learners engagement and enthusiasm for learning (Christensen et al. 2010). Multiple intelligences teaching provides educators with a conceptual framework for organizing and reflecting on curriculum assessment and pedagogical practices. In turn, this reflection has led many educators to develop new approaches that might better meet the needs of the range of learners in their classrooms (Smith 2002). From what other scholars have written about multiple intelligences teaching, it is evident that there are many benefits from understanding and using multiple intelligences teaching.

\section{Developing Multiple Intelligences in Learners}

Gardner (1995) insists that everyone has the capacity to develop all eight intelligences to a competent level of performance, if appropriate encouragement, enrichment and instruction is given. Miller concurs that multiple intelligences can be developed to a level of competence depending 


\section{N. Pearl Blose \& Blanche N. Hadebe-Ndlovu}

upon three factors: Hereditary, which has everything to do with one's genetic makeup. Experience, which includes experience with family, school, friends and all others who help in developing intelligence, keep them from developing or actively suppress them. Miller maintains that there are two types of experiences that can affect the development of intelligences: the crystallising experience and paralysing experience. Crystallising experience refers to an experience which acts as a spark that lights intelligence and starts its development towards an adequate level of competency. On the other hand paralysing experience refers to an experience that deactivates or discourages the development of intelligence. For an example a learner who confidently tries an experiment in chemistry class and it turn out to be a flop. Then the teacher humiliates him in front of the class. This particular learner will be filled with a lot of negative feelings (shame, anger, fear and guilt). This paralysing experience will hinder some of the learner's intelligences from developing. Therefore learners come into the classroom with different sets of developed intelligences, which means that each child will have his own unique set of intellectual strengths and weaknesses (Brualdi Timmins 1996). This will be mainly due to the experiences that learners have been exposed to prior to coming to the classrooms. History and culture, also historical background of an individual can awaken or hinder intelligences from being developed. This includes time and place of birth and where one is raised. As a result it is very important for teachers to understand the intelligences in their class, taking into account the context (in this study: the rural school).

Campbell and Linda (1996) agree that intelligences can be developed. They suggest that there are influences that can either promote or suppress the development of intelligences. They state that the development of intelligence can be influenced by: access to resources for example growing up in a home where there is no musical instrument, may suppress the child's development of musical intelligence. Geographic factors for example, a learner who grew up in a rural area will have more chances to develop naturalist intelligence as compared to a learner who grew up in urban setting, staying in a $32^{\text {nd }}$ floor in a flat in Ballito. From what these Scholars have written, it is clear that it is important for teachers to understand multiple intelligences in their classes, so that they may be able to teach effectively. Teachers have to also understand their own dominant, well developed intelligences and their undeveloped intelligences so that they may work on developing them. If the teacher understands multiple intelligence teaching strategies, she may ask learners to 
help her out when there is a need. It is possible that some learners may show expertise in an area where the teacher's particular intelligence is not well developed. For example a teacher might avoid drawing diagrams on the chalkboard or avoid using pictures as teaching aids, possibly because her spatial intelligence is not well developed. There might be learners who are well developed in this intelligence.

\section{Multiple Intelligences in the Classroom}

There are many ways to incorporate Multiple Intelligences theory into the physical science curriculum, and there is no set method by which to incorporate the theory. It is important for teachers to carefully select activities that not only teach to the intelligences, but also realistically match with the subject matter of the lesson. Multiple Intelligences theory should enhance, not detract from what is being taught (Giles et al. 2003). Teaching physical science is not just about giving out facts in the textbooks, it involves helping learners to understand the world. This includes helping learners to use their skills of observing, measuring, describing, classifying, experimenting and predicting. Douglas, Burton, and Reese-Durham (2008) contend that there is a need for teachers to adopt strategies that could lead to better performance in the academic achievements of learners. When teaching an individual, teachers should present the most difficult concepts in the learner's preferred style. Easier concepts should be introduced in a different style. When teaching the entire class, teachers should use different teaching methods to cater for all learning styles in their presentations, if they are to reach every learner (Giles et al. 2003). In an effort to maximise learners' interest in both the subject matter and their own learning inclination, teachers may wish to teach their students a little bit about Multiple Intelligences. Teachers can brief the class about each type of intelligence and then follow up with a self-assessment for each learner. In this way, learners will be able to capitalise on their strengths and work on their weaker areas (Giles et al. 2003). The multiple intelligence theory gives a clear guide on how teachers can plan their lessons to cater for all differences in learners' abilities. The MI theory also provides a guide on how teachers can help learners to develop the above-mentioned skills as physical science demands.

Multiple Intelligences teaching, is based on the idea that, intelligences are not singular but multiple. Every person has a unique blend of intelligences. Intelligences vary with regard to their development. All the intelligences are 


\section{N. Pearl Blose \& Blanche N. Hadebe-Ndlovu}

not static but dynamic. The use of one intelligence can enhance another of the intelligences (Armstrong 1994). This means that intelligences can be developed. Intelligences vary with regard to their development. The Multiple Intelligences Theory suggests that learners learn in different ways. Knowing learners' learning strengths and weaknesses will assist teachers in trying new ways of teaching. It will also help teachers in planning according to the classroom's abilities.

Kegan and Kegan (1998) defines multiple intelligence teaching as a powerful catalyst in education: it is revitalising the search for more authentic, learner-centered approaches to the curriculum, instruction and assessment. Multiple Intelligences teaching, is based on the idea that, intelligences are not singular but multiple. Every person has a unique blend of intelligences. Intelligences vary with regard to their development. All the intelligences are not static but dynamic. The use of one intelligence can enhance another of the intelligences (Armstrong 1994). This means that intelligences can be developed. Intelligences vary with regard to their development. The Multiple Intelligences Theory suggests that learners learn in different ways. Knowing learners' learning strengths and weaknesses will assist teachers in trying new ways of teaching. It will also help teachers in planning according to the classroom's abilities.

In the traditional classroom, learners with different ways of learning are often labelled as learning disabled, as having attention deficit disorder (ADD) or simply as underachievers, when their unique ways of thinking and learning are not addressed by a heavily linguistic or mathematical classroom (Armstrong 2014) Multiple Intelligences teaching helps teachers realise how smart their learners are by providing them with different options of teaching. In order to get rid of the perception that science is abstract and difficult to be understood, instead of straight explanation methods, Multiple Intelligences teaching methods which get positive feedback should be used. (Ucak, Bag \& Usak 2006).

The guiding principle for multiple intelligences is that, whatever one teaches, he has to link the teaching objective with words, numbers, pictures, music, the body, social interactions and personal experience (Armstrong 2009). When teaching an individual, teachers should present the most difficult concepts in the learner's preferred style. Easier concepts should be introduced in a different style. When teaching the entire class, teachers should use different teaching methods to cater for all learning styles in their presentations, 
if they are to reach every learner (Giles et al. 2003).

A basic understanding of each of the intelligences shows that they can work together or separate. For example, a dancer can excel in his art only if he has also musical intelligence to distinguish the different rhythms and patterns in music, interpersonal intelligence to grasp how he can emotionally move his audience through his movements, as well as bodily intelligence to complete the movements successfully (Fogarty 2015).

The more thoroughly teachers understand the differences in learners, the better chance they have of meeting the diverse learning needs of all of their learners. There are three categories of diversity that have important implications for teaching and learning, they are; differences in learning styles, approaches to learning, and intellectual development levels (Felder \& Brent 2005). The way in which a learner approaches or responds to the learning task comprises two aspects: first, cognitive style, which reflects the way in which the individual person thinks; second, learning strategy, which reflects those processes which are used by the learner to respond to the demands of a learning activity. A person's cognitive style is probably an in-built and automatic way of responding to information and situations. A learner's cognitive style influences his or her general achievement in learning situations (Riding \& Rayner 2013).

\section{Planning and Implementing Learner Centered Lessons}

Giles (2003) suggests that teachers have to be careful when planning a lesson to use multiple intelligences strategies. He advised that teachers have to consider activities that can be integrated into the lesson that teach to the different intelligences. Teachers need not incorporate all eight intelligences into one lesson. When gathering resources and materials, they should consider those which will allow learners to explore their multiple intelligences. When designing activities and tasks for the intelligences, teachers have to design activities that are learner-centered.

\section{Assessment in Multiple Intelligences}

According to Lam (1995), a fair assessment is one in which students are given equitable opportunities to demonstrate what they know. Effective assessment is in alignment with instructional practices (Bellanca, Chapman \& Swartz 
1994). Changing teaching strategies and curricula without changing assessment methods will not bring about the full benefit of MI theory for teaching and learning. Thus, if MI theory is to be used in classrooms, teachers must change the way they assess learning (Chapman 1993). According to Stanford (2003) traditional assessment limits learners to a pencil-and-paper test as the primary means of demonstrating knowledge and skills. MI theory brings about an awareness of many assessment strategies that allow learners to show that they understand and can use new information in unique ways. Assessment alternatives include $\operatorname{logs}$ and journals, graphic organizers, observational checklists, video samples, rubrics, miscue analyses, and portfolios.

Such alternative forms of assessment offer learners the potential to demonstrate learning content in a variety of ways. In the multiple intelligence classroom, assessment and instruction are partners. The MI classroom provides the environment for teachers to use varied teaching strategies, expanded curricula, and authentic assessment to provide creative and active learning that engages all learners (Stanford 2003).

\section{The Theoretical Framework of the Study}

The (MI) theory was proposed by Howard Gardner, the Harvard University professor. Gardner introduced the MI theory in his book, The frames of mind: The theory of multiple intelligence (Howard 1983). He proposed that individuals possess intellectual abilities which enable them to solve problems, create products or provide services that are valued in the larger society (Howard 1983). In his theory Gardner argues that the intelligence is not a single entity which can be measured by an IQ test. He defines intelligence as the ability to solve problems. He suggested that everybody possess a different mind and each individual has a personal intelligence profile, which consists of eight different intelligence types. We all share the whole spectrum of intelligences and intellectual strengths which change over time depending on experience and practice (Gardner 1999). The Multiple Intelligences theory holds that each person possesses eight intelligences, and uses them to carry several kinds of tasks. Although individuals possess all eight intelligences, each has their own particular mix of intelligences, with some dominating over others, but they are not fixed and can change over time. This means each individual has his/her own intelligence profile. 


\section{Types on Intelligences}

The eight intelligence types as explained by the MI theory are:

\begin{tabular}{|l|l|}
\hline $\begin{array}{l}\text { Multiple } \\
\text { Intelligences }\end{array}$ & $\begin{array}{l}\text { Agreement with the theory and understanding } \\
\text { multiple intelligences }\end{array}$ \\
\hline - Visual & $\begin{array}{l}\text { Spatial intelligence, is the capacity to recognize and use } \\
\text { the patterns of wide space and more limited areas } \\
\text { (Howard Gardner 1999). It means being picture smart } \\
\text { and having the ability to sense form, space, colour, line } \\
\text { and shape. It includes the ability to graphically represent } \\
\text { visual ideas. Learners, who have a well-developed } \\
\text { spatial intelligence, enjoy art activities, reading maps, } \\
\text { charts and diagrams, thinking in images and pictures. } \\
\text { According to Armstrong (1994) these students have } \\
\text { highly developed senses for color, line, shape, form, } \\
\text { space. They also have the ability to visualize ideas. }\end{array}$ \\
\hline - Mathematical & $\begin{array}{l}\text { Mathematical intelligence, according to Gardner (1999) } \\
\text { this intelligence is based on the sensitivity and capacity } \\
\text { to perceive logical or quantitative matters. This } \\
\text { intelligence is comprised of classification and } \\
\text { categorization of logical patterns, the ability to deduce } \\
\text { clear information, numerical and logic. Learners with } \\
\text { mathematical intelligence enjoy mathematics. }\end{array}$ \\
\hline - Naturalistic & $\begin{array}{l}\text { Musical intelligence means being able to sense rhythm, } \\
\text { pitch, and melody. Musical intelligence includes skills } \\
\text { like the ability to recognize simple songs and to vary } \\
\text { speed, tempo, and rhythm in simple melodies. Linguistic } \\
\text { intelligence-Gardner (1999) defines linguistic } \\
\text { intelligence as; the ability to effectively use the words, } \\
\text { both orally and in writing. It has to do with being word } \\
\text { smart. It includes the ability to remember information. }\end{array}$ \\
\hline $\begin{array}{l}\text { The research participant no. 4 contradicted himself, in } \\
\text { his narrative he expressed that MI techniques are not } \\
\text { applicable to physical science. Also when he was } \\
\text { interviewed, he explained that he does not consider } \\
\text { using multiple intelligences strategies because they } \\
\text { consume a lot of time. }\end{array}$ \\
\hline Musical
\end{tabular}




\begin{tabular}{|l|l|}
\hline - Verbal \\
linguistic & $\begin{array}{l}\text { Spatial intelligence, is the capacity to recognize and use } \\
\text { the patterns of wide space and more limited areas } \\
\text { (Howard Gardner 1999). It means being picture smart and } \\
\text { having the ability to sense form, space, colour, line and } \\
\text { shape. It includes the ability to graphically represent } \\
\text { visual ideas. Learners, who have a well-developed spatial } \\
\text { intelligence, enjoy art activities, reading maps, charts and } \\
\text { diagrams, thinking in images and pictures. }\end{array}$ \\
\hline - Kinetic & $\begin{array}{l}\text { Spatial intelligence, is the capacity to recognize and use } \\
\text { the patterns of wide space and more limited areas } \\
\text { (Howard Gardner 1999). It means being picture smart and } \\
\text { having the ability to sense form, space, colour, line and } \\
\text { shape. }\end{array}$ \\
\hline - Intrapersonal \\
\hline $\begin{array}{l}\text { An intrapersonal intelligent person is someone with the } \\
\text { ability to understand himself, his strengths, his } \\
\text { weaknesses, moods, desires, and intentions. This includes } \\
\text { understanding how one is similar to or different from } \\
\text { others. Knowing how to handle one's feelings, such as } \\
\text { what to do, and how to behave in any situation. } \\
\text { Intrapersonal intelligence is based on the capacity to } \\
\text { reflect introspectively, and is the ability to find meaning in } \\
\text { the actions of the individual. }\end{array}$ \\
$\begin{array}{l}\text { Learners with a well-developed intrapersonal intelligence } \\
\text { establish and maintain good social relationships; they are } \\
\text { friendly and have a good sense of humor. They perceive } \\
\text { the feelings, thoughts, motivations, behaviors and } \\
\text { lifestyles of others through listening, engaging with } \\
\text { others' problems and are interested in helping. They } \\
\text { assume different roles within the group and are open to } \\
\text { understanding other's points of view. } \\
\text { Bodily intelligence is the ability to use the body } \\
\text { expressively in different ways. It means being body smart. } \\
\text { It means being able to co-ordinate mind with body. This } \\
\text { includes the ability to use one's body to express ideas and } \\
\text { feelings. It also includes physical skills such as co- } \\
\text { ordination, flexibility, speed, and balance. }\end{array}$ \\
\hline
\end{tabular}




\section{- Existential Learning is reflecting on and observing one's thoughts feelings and regulating ideas effectively.}

Learners with a dominant linguistic intelligence like to learn new words and play with language crosswords puzzles. They are enchanted by stories and are able to relate occurrences. They have a passion for the meaning of the words, lyrics of songs. Learners with linguistic intelligence can tell stories. They are able to start conversations or discussions and they are well expressed both orally and in writing. They also like reading books.

Mathematical intelligence, according to Gardner (1999) this intelligence is based on the sensitivity and capacity to perceive logical or quantitative matters. This intelligence is comprised of classification and categorization of logical patterns, the ability to deduce clear information, numerical and logic. Learners with mathematical intelligence enjoy mathematics. They like to discover how things work and they create personal strategies to solve problems. They are able to breakdown events into various stages, and they enjoy the computer. Learners with this type of intelligence have sharp analytical skills, and find it easy to synthesise, deduct and compare information.

Musical intelligence means being able to sense rhythm, pitch, and melody. Musical intelligence includes skills like the ability to recognize simple songs and to vary speed, tempo, and rhythm in simple melodies. Musical intelligence is the skill to do and appreciate the performances, and composition of musical patterns. It involves the capacity to recognize and compose music, understand tones, and rhythms. According to Gardner (1999) musical intelligence is parallel to linguistic intelligence. He explains that learners with dominant musical intelligence enjoy music and this gives them an advantage in reading and writing better because similar sounds and speech are present in linguistic intelligence. They also can create music and enjoy singing songs. The musical part of their brains can be motivated by clapping hands, snapping fingers, chanting words or moving rhythmically.

Spatial intelligence, is the capacity to recognize and use the patterns of wide space and more limited areas (Howard Gardner 1999). It means being picture smart and having the ability to sense form, space, colour, line and shape. It includes the ability to graphically represent visual ideas. Learners, who have a 
well-developed spatial intelligence, enjoy art activities, reading maps, charts and diagrams, thinking in images and pictures. According to Armstrong (1994) these students have highly developed senses for color, line, shape, form, space. They also have the ability to visualize ideas. Learners with a well-developed spatial intelligence, have very unique ability of using imagination. They are also very aware of the space around them and are very good at recognising images.

Interpersonal intelligence is the capacity to understand the intentions, motivations and desires of others. It means being people smart. It is the ability to understand another person's moods, feelings, and intentions. It includes such skills as responding effectively to other people. It allows people to work effectively with others and for that reason cooperative learning is effective. The people with this type of intelligence make good educators, salespeople, religious and political leaders (Howard Gardner 1999). Learners with dominant interpersonal intelligence prefer to be with people. They are friendly and can get on well with others, so they can easily take part in social activities. These learners are assertive, express their feelings, they make their ideas clear, and can empathise with others in the group. Learners with interpersonal intelligence manifest their ability to work in group with their classmates. They have the ability to resolve conflicts and to integrate different personalities.

Learners with a well-developed intrapersonal intelligence establish and maintain good social relationships; they are friendly and have a good sense of humor. They perceive the feelings, thoughts, motivations, behaviors and lifestyles of others through listening, engaging with others' problems and are interested in helping. They assume different roles within the group and are open to understanding other's points of view. Bodily intelligence is the ability to use the body expressively in different ways. It means being body smart. It means being able to co-ordinate mind with body. This includes the ability to use one's body to express ideas and feelings. It also includes physical skills such as co-ordination, flexibility, speed, and balance. This is the ability humans have to perform physical movements such as dance, theater, aerobics, athletics, etc. and is related to both working and developing aspects such as flexibility, balance, speed, coordination, strength and perception.

The naturalist intelligence, according to Gardner (1999) is the intelligence that is associated with students who are in harmony with nature. It is the ability 
to distinguish, categorise and analyse elements of the environment such as urban and rural objects, animals, and plants. It is well-developed in learners who are sensitive to environmental problems and who are able to recognise and classify plants, animals and minerals including rocks. Learners who are dominant in this type of intelligence like participating in outdoor activities in natural settings. They are nature smart and are respectful with the environment. Gardner (1999) also argues that most tasks require more than one intelligences working together.

\section{Data Presentation}

Initially participants were asked to write narratives on their understanding of multiple intelligences in teaching physical science. Later semi structured interviews were conducted. Lastly classroom observations were done.

On the question asked: What is your understanding of multiple intelligences in teaching physical science?

The research participant 1 responded:

I think multiple intelligences teaching is used when the teacher recognises that every student is special and unique. The teacher needs to teach in such a way that all learners benefit from his or her teaching. The physical science teacher has to involve all learners when teaching. There are learners that are active in answering verbally in class and there are those that will surprise you during the test or exam. It is important to have different level tasks in an assessment, like multiple choice, one word answers, and also long questions requiring calculations, discussion and describe. It is important at times to allow learners to teach one another in groups or in pairs because some learners are shy to ask in class even when they do not understand. Such learners might find it easy to ask from other learners. The other important thing is that the teacher must prepare and explain nicely for all learners to understand. The teacher has to give extra work to the fast learners while repeating and answering questions from those that are not as fast. Multiple intelligence teaching should be done in all classed not in grade 10 only. The danger in not taking multiple intelligences into consideration is that some learners may find your lessons boring and could end up failing the subject or dropping it altogether. 
On the same question research participant 2 responded:

I understand that learners have different ways of understanding what they are taught due to their different intelligences which vary from learner to learner. From what I know learners may be visual, auditory or kinesthetic. These three types of learners happen to be in one class which makes it difficult to reach out to all of them at the same time. For physical science in grade 10, we as teachers are guided by the Annual Teaching Plan (ATP), as a result due to trying to keep up with the ATP, we end up focusing to one or two types of intelligences. We as teachers, also fall amongst certain type of intelligences, so we tend to make our lessons focus on more on that intelligence, especially in subjects like physical science. For instance, if a teacher is more kinesthetic he or she will make his or her lessons more practical without noticing that learners who are auditory are sacrificed in that process. In conclusion, I think incorporating different multiple intelligences in our teaching of physical can make learners understand better. It would be convenient if the curriculum can be shaped in a manner that will allow teachers to use multiple intelligences.

On the research question about understanding multiple intelligences in teaching physical science, research participant 3 responded:

My understanding of multiple intelligences in teaching physical science is that to teach physical science one has to deal with diverse class of learners with different learning styles. What causes this is the fact that learners' backgrounds are different. Some are from homes where parents can afford to buy everything the learner needs whereas some are from homes where no one is working, and parents are struggling to put food on the table, not to mention school needs. The physical science teacher has to teach in such a way that she accommodates all learners. There are learners that are active in answering questions in class; there are also those that will surprise you in a test. It is important to make different tasks when assessing, like multiple choice, one word and also long questions that will require one to describe, explain or discuss. It is also important to allow learners to learn from each other, by letting them have group 
discussions or discuss in pairs. This is important because some learners are shy to ask in class, even when they do not understand. Such learners may find it easy to ask from other learners. Team teaching also helps to achieve multiple intelligences in teaching. If you are not comfortable with the topic, you have to ask your colleague who is comfortable to do it.

Surprisingly on the same research question, research participant 4 s' response was:

Multiple intelligences is about using all different intelligences in a learner to make sure he understands what is taught. The multiple intelligence way of teaching is applicable when the class has few learners. Multiple intelligences teaching is not applicable to physical science because, physical science is a formal subject. It needs learners to focus, unlike the languages and L.O. which can be taught in the sports field. What I understand is that there are learners who are gifted in music but they cannot use it in physical science, because it is irrelevant to physical science. Physical science cannot be done by all learners; it requires skills that not all learners possess. It demands skills such as scientific reasoning, which cannot be taught. Learners should know themselves well and know their abilities. They should know what they can do and what they cannot do, so that they make a wise choice of subjects. It is also critical that the school provide proper guidance to grade 9 on subject choices. The most important thing is that the teacher must know the subject matter. He must be able to explain any concept. The teacher must give extra work to fast learners while doing remedial work with the slow learners. Multiple intelligence teaching is one of the new methods of teaching, it consumes a lot of time, doing all activities. There is a lot of content to be done in physical science, if one would follow multiple intelligence teaching, I am sure only half a year's work would be taught by end of the year.

The recorded semi-structured interviews were transcribed into The main question in this section was: what are teachers' understandings of multiple intelligences in teaching physical science in grade ten? During the semi- 


\section{N. Pearl Blose \& Blanche N. Hadebe-Ndlovu}

structured interviews, after the rapport was established, the above question was asked to initiate the semi-structured interviews and to direct it. The semistructured interview was then allowed to flow natural. All questions asked were seeking to determine whether grade ten physical science teachers understand multiple intelligence teaching or not, whether they use the MI strategies in their teaching and why they understand multiple intelligences in particular ways. Interview questions also tried to determine whether teachers are willing to use MI strategies in their teaching.

\section{Data Analysis}

Dawson (2010) states that in qualitative research, data is based on human experiences and observations. As this study explored teachers' understanding, I was more interested in the experiences of the participants. Information was generated using narratives, semi-structured interviews and classroom observations. The study focused on grade 10 physical science teachers. Participants were interviewed (one on one) for approximately 40-60 minutes per session. Semi-structured interview were voice-recorded for convenience of transcription. To analyse data the recordings were transcribed into written form, notes were analysed by selecting what is significant to the research topic. The researcher synthesised using coding, highlighting different concepts organising codes into themes and categories

\section{Findings}

Physical science teachers do not take multiple intelligences as a serious and significant part of learning. Gardner (1983) states that all the eight intelligences are equally important and essential to an individual's development. Therefore, development in one area often increases the chances of development of another. Gardner (1999) asserts that when it comes to being smart, differences count. Some research participants' responses were surprising, for an example; that some teachers felt focusing on multiple intelligences was a waste of time, and there were no resources to assist them with the different skills. Participants showed a lack of understanding of multiple intelligences teaching because they blamed failure to incorporate MI teaching to lack of resources, whereas multiple intelligences require teachers to be aware of different intelligences in the classroom, but in terms of resources- there is nothing special needed. 
Gardner (1999) intelligence is the ability to solve problems and to create issues in the cultural medium in order to progress. The participants' common response was that the method is time consuming. The participants' opinion that multiple intelligences teaching consume a lot of time and the pressure to produce good results is the main reason for teachers not using multiple intelligences teaching in their classrooms. The fear to lose their jobs if learners do not pass physical science pushes them to desperately teach only guidelines for exams, with the hope of teaching exactly what will be asked during exams.

\section{Conclusion}

The data generated from four grade ten physical science teachers revealed that there are non-understandings, limited understandings and misunderstandings of multiple intelligences in teaching physical science in grade ten teachers in the rural schools.. Almost all research participants acknowledged that, they have little, non-understanding or misunderstanding of multiple intelligences teaching. Teachers blamed high failure rate to lack of resources which is a serious challenge in the rural schools. It was noted that some of the qualified teachers were not retained in rural areas as the schools in townships and urban were attracting the qualified teachers.

\section{References}

Akinmade, O.T.C. 1999. Scientific Literacy in Nigeria: The Progress, Prospect and Challenges for the $21^{\text {st }}$ Century. Paper presented at the $9^{\text {th }}$ symposium of the international organization for science and technology education.

Armstrong, T. 1994. Multiple Intelligences: Seven Ways to Approach Curriculum. Educational leadership, 52,3: 26 - 28.

Armstrong, T. 2009. Multiple Intelligences in the Classroom. Alexandria, USA: Ascd.

Behi, R. \& M. Nolan 1995. Ethical Issues in Research. British Journal of Nursing 4,12: 712 - 716.

https://doi.org/10.12968/bjon.1995.4.12.712 PMid:7580079

Bellanca, J., C. Chapman \& E. Swartz 1994. Multiple Assessments for Multiple

Intelligences. Palatine, IL: IRI: Skylights Publishing.

Brualdi Timmins, A.C. 1996. Multiple Intelligences: Gardner's Theory. 
Practical Assessment, Research \& Evaluation 5,10: 3.

Burney, V.H. \& J.R. Beilke 2008. The Constraints of Poverty on High

Achievement. Journal for the Education of the Gifted 31,3: 295 - 321.

https://doi.org/10.4219/jeg-2008-771

Campbell, L., B. Campbell \& D. Dickinson 1996. Teaching \& Learning through Multiple Intelligences. USA: Pearson \& ERIC.

Chapman, C. 1993. If the Shoe Fits... How To Develop Multiple Intelligences in the Classroom. Palatine: ERIC.

Christensen, C.M., C.W. Johnson \& M.B. Horn 2010. Disrupting Class. New York: McGraw-Hill.

Collins, H. 2004. Collins English Dictionary. Glassgow: HarperCollins.

Dawson, C. 2010. Introduction to Research Methods: A Practical Guide for

Anyone Undertaking a Research Project. United kingdom: Oxford.

Douglas, O., K.S. Burton \& N. Reese-Durham 2008. The Effects of the Multiple Intelligence Teaching Strategy on the Academic Achievement of

Eighth Grade Math Students. Journal of Instructional Psychology 35,2: 182 - 188.

Felder, R. M. \& R. Brent 2005. Understanding Student Differences. Journal of Engineering Education 94,1: 57 - 72.

https://doi.org/10.1002/j.2168-9830.2005.tb00829.x

Fogarty, R. 2015. Understanding the Theory of Multiple Intelligences. Early

Childhood Today. Avaialble at: Academic Search Premier Database.

(Accessed on 3 Decemebr 2018.)

Gardner, H. 1983. Frames of Mind: The Theory of Multiple Intelligences. New York: Basic Books.

Gardner, H. 1995. Reflections on Multiple Intelligences: Myths and Messages. Phi Delta Kappan 77,3: 200.

Gardner, H. 1999. Intelligence Reframed: Multiple Iraellibencies for the $21^{\text {st }}$ Century. New York: Basic Books.

Gardner, H. 2016. Audiences for the Theory of Multiple Intelligences. Teachers College Record. Academic Search Premier Database. Available at:

https://tinarussell.weebly.com/uploads/5/2/2/1/5221134/audiences_for_t heory of mi gardner.pdf

(Accessed on 6 March 2018.)

Giles, E., S. Pitre \& S. Womack 2003. Multiple Intelligences and Learning Styles. In Orey, M. (ed.): Emerging Perspectives on Learning, Teaching, 
and Technology. CreateSpace Publishers.

Howard, G. 1983. Frames of Mind: The Theory of Multiple Intelligences. New York: Basics.

Kagan, L. 2000. Multiple Intelligences: Structures \& Activities. Cheltenhem: Hawker Brownlow Education.

Kagan, S. \& M. Kagan 1998. Multiple Intelligences. The Complete MI Book. San Clemente, CA: Kagan Cooperative Learning.

Lam, T. 1995. Fairness in Performance Assessment. ERIC Digest.

Noble, T. 2004. Integrating the Revised Bloom's Taxonomy with Multiple Intelligences: A Planning Tool for Curriculum Differentiation. Teachers College Record 106,1: 193 - 211.

https://doi.org/10.1111/j.1467-9620.2004.00328.x

Riding, R. \& S. Rayner 2013. Cognitive Styles and Learning Strategies: Understanding Style Differences in Learning and Behavior. London: David Fulton Publishers. https://doi.org/10.4324/9781315068015

Smith, M.K. 2002. Howard Gardner and Multiple Intelligences. The Encyclopedia of Informal Education 15. Available at:

https://infed.org/mobi/howard-gardner-multiple-intelligences-andeducation/

Stanford, P. 2003. Multiple Intelligence for Every Classroom. Intervention in School and Clinic 39,2: 80 - 85.

https://doi.org/10.1177/10534512030390020301

Ucak, E., H. Bag \& M. Usak 2006. Enhancing Learning through Multiple Intelligences in Elementary Science Education. Journal of Baltic Science Education 10.

N. Pearl Blose WANDYB Solutions - Skills Development Company PhD Student University of KwaZulu-Natal ncane.blose@yahoo.co.za

Blanche Ntombizodwa Hadebe-Ndlovu School of Education University of KwaZulu-Natal ndlovubl@ukzn.ac.za blanchendlovu@ymail.com 